\title{
Utilización de protectores superficiales para la conservación de la piedra: situación actual en España ( $\left.{ }^{*}\right)$
}

\author{
The use of surface protectants: \\ the current situation in Spain ( $\left.{ }^{*}\right)$
}

\author{
ROSA MARIA ESBERT \\ Departamento de Geología (Petrología) \\ Universidad de Oviedo. 33080 OVIEDO (ESPAÑA)
}

Fecha de recepción: 22-X-92

\author{
RESUMEN \\ En este artículo se hace una revisión sobre el estado \\ actual en España, de los trabajos e investigaciones \\ referidas a la utilización de protectores superficiales para la \\ conservación de la piedra.
}

Se hace referencia a los parámetros y ensayos de durabilidad más frecuentemente utilizados, en el laboratorio, para predecir la idoneidad de los diferentes tratamientos.

También se resalta la importancia que sobre la durabilidad de la piedra tienen los cambios infringidos por el tratamiento en la configuración del sistema poroso de ésta, una vez tratada.

Se muestran diversos ejemplos, referidos a los aspectos mencionados, seleccionados de la bibliografía científica española más reciente.

\begin{abstract}
$S \cup M M A R Y$
In the present paper a review is made about the works and researches related to the use of superficial protectants for the stones conservation in Spain.

It deals with the parameters and durability tests most frequently used in laboratories, in order to foretell the suitability of the different treatments.
\end{abstract}

It is also pointed out the significance that on the stone durability have the changes undergone by the treatment in the configuration of the pore system of the treated stone.

Several examples selected from recent scientific bibliography are shown and related to the aspects above mentioned.

\section{INTRODUCCIÓN}

En primer lugar recordar que esta síntesis se refiere al concepto actual de protección de la piedra monumental que consiste en la introducción de una barrera, entre la superficie de la piedra y el ambiente, que sin modificar el aspecto superficial de la misma, la aísle de la acción de los agentes de alteración.

(*) Este artículo se basa, en parte, en la Ponencia que sobre dicho tema se presentó en la Mesa Redonda que tuvo lugar en la 3rd International "Conference on Non-destructive Testing Study and Conservation of Works of Art", celebrada en Viterbo (Italia) los días 5 y 6 de octubre de 1992.

\section{INTRODUCTION}

This synthesis is about the present concept of monumental stone protection, consisting in the insertion of a barrier between the surface of the stone and the environment, without modifying its superficial aspect and protecting the stone from weathering agents.

(") This article is partially based on the communication that was presented about this topic in a workshop in the $3^{\text {rd }}$ International "Conference on Non-destructive Testing for Study and Conservation of Works of Art", held in Viterbo (Italy) the $5^{\text {th }}$ and $6^{\text {th }}$ of October, 1992. 
En la práctica esto suele conseguirse aplicando productos hidrofugantes a la superficie de la piedra, o a los sistemas piedra-consolidante, si ésta requiere, para su conservación, una consolidación previa.

Con ello se dificulta en mayor o menor medida el contacto y la penetración de agua en la piedra, y al mismo tiempo, se minimizan o evita la acción de otros agentes de alteración que ésta lleva habitualmente disueltos o en suspensión.

En la actualidad los productos más usados en el continente europeo para dicha protección, son de naturaleza orgánica o productos a base de silicio (silicorgánicos).

En España, aunque su utilización no está muy generalizada, se vienen empleando para proteger piedras monumentales de diferente naturaleza, características petrofísicas y tipo de alteración. Incluso en algún caso, las losetas de piedra de revestimiento, empleadas en algunos edificios actuales, se han hidrofugado antes de su puesta en obra.

La aplicación de protectores se ha llevado a cabo, en diversas ocasiones, sin conocer previamente las características más elementales que controlan el grado de idoneidad de los productos empleados en relación con el material rocoso y el ambiente específico donde éste se halla emplazado.

Sin embargo y aunque esto continúe sucediendo, en el ámbito de los profesionales responsables de las intervenciones en piedra, se va tomando conciencia de la importancia que tienen los estudios previos. En particular los referentes a diagnóstico de lesiones y sugerencias de tratamiento, para garantizar una buena evolución de los mismos.

Actualmente ya algunos gobiernos autonómicos, como por ejemplo la Junta de Andalucía, requieren la incorporación de estos estudios en los Proyectos de Intervención.

Por otra parte, cada vez son más numerosas las investigaciones que se están llevando a cabo en diversos centros dependientes de organismos públicos; Universidades, Institutos del Consejo Superior de Investigaciones Científicas, etc., para comprobar, en el laboratorio, la eficacia y durabilidad de los productos químicos que, a nivel mundial, ofrece el mercado para esta finalidad y, si es posible, transferir las experiencias adquiridas al monumento.

También, en ciertas intervenciones de conservación en piedra relativamente recientes,
In practice this is usually achieved by applying hydrophobic products, on the surface of the stone or on the stone-consolidant system, if the stone requires for its conservation a previous consolidation.

This hinders, more or less, the contact or water penetration in the stone and, at the same time, it miniminizes or avoids the action of other weathering agents or substances that usually are dissolved or in suspension in water.

These products are being used in Spain, though not widely, in order to protect monumental stones of different nature and petrophysical characteristics. Even in some cases the slab stones for cladding, used in some current buildings, have been protected before starting works.

Nowadays the most common products used for this protection are of organic nature or with silicon (silico-organics).

The application of protectants has been carried out in many cases without knowing previously the characteristics which regulate the suitability of the products used to protect each particular type of stone material, in the specific environment where it is located.

However, and though this still goes on, the scope of professionals responsible of the intervention in the stone is becaming aweare of the importance that there previous studies have; particullary in relation to diagnosis of lesions and suggestions about treatments, to guarantee a good evolution of the interventions.

Nowadays some administration of spanish Autonomies such as "Junta of Andalucia", demanded the inclusion of these studies in the Intervention Projects.

However, and though this situation still goes on, more and more researches are being carried out in several institutions dependent on public organisms: Universities, Scientific Institutes ("Consejo Superior de Investigaciones Cientificas"), etc... to check, in the laboratory, the effectivenness and durability of the chemical products available in the market for this purpose, and to transfer the obtained experiences to the monument as far as possible.

Previous studies of the stone materials, its deterioration and conservation as well a further 
en monumentos muy significativos del Patrimonio arquitectónico español, como por ejemplo las fachadas del Museo del Prado o el Frontón de la Biblioteca Nacional en Madrid (1985), La Pedrera de Gaudi en Barcelona (1988), la fachada del antiguo Hospicio Provincial de Oviedo (1990), entre otros, se han realizado estudios previos de los materiales pétreos, de su deterioro y conservación, así como, el posterior seguimiento de los trabajos de intervención en la piedra, por parte de especialistas.

Sin embargo, en España continúa sin contemplarse la fase de mantenimiento e inspección cíclica de la obra de conservación. Esta fase es fundamental en todos los casos y de forma especial después de una intervención en piedra, en la que se han aplicado productos de tratamiento. El control de la evolución "in situ" de los productos de mayor interés permitiría, además, disponer de un banco de datos sobre su comportamiento y el de los factores que intervienen en dicha evolución.

\section{INVESTIGACIONES}

Las investigaciones llevadas a cabo en los laboratorios se centran por lo general, en medir con normas estandarizadas (C.N.R.-I.C.R. o I.S.R.M., etc.) o con recomendaciones (R.I.L.E.M.), ciertas propiedades físicas significativas, en las piedras sin tratar y tratadas analizando posteriormente las características de los sistemas piedra-tratamiento, que han motivado las variaciones en el valor de dichas propiedades.

Las propiedades físicas que suelen medirse, son las relacionadas con el aspecto macroscópico y brillo de las piedras - color-, con los espacios vacíos -densidad y porosidad abierta-, con la captación y transferencia de humedad por el interior de la piedra - humedad y grado de saturación, succión capilar, absorción y desorción de agua, permeabilidad al vapor-, con el hinchamiento en aquellas variedades que poseen arcillas expansivas -expansión hídrica lineal o volumétrica- con el comportamiento mecánico -módulo de elasticidad, resistencia mecánica-, con el comportamiento térmico -expansión térmica lineal o volumétrica-, con la mayor o menor hidrorrepelencia de la superficie -ángulo de contacto-, etc. Las propiedades, en algunos casos suelen volverse a medir después de los ensayos de envejecimiento artificial acelerado, con la finalidad de relacionar la durabilidad del material ensayado, sin tratar y tratado, el agente alterante seleccionado y las variaciones en ellas inducidas. folow-up of relatively recent intervention works, have been carried out by specialists in very ouststanding monuments of the Spanish Architectural Heritage, such as: the Façades of the Prado Museum and the Front of the National Library in Madrid, (1985), Gaudi's "La Pedrera" in Barcelona, (1988), the Ancient Pilgrims Hospital in Oviedo, (1990), among others.

The steps of maintenance and cyclic inspection of the conservation work are not still regarded in Spain. This step is basic in every situation, specially after any intervention on the stone, treated whit products. The evolution "in situ" of those products is of a major interest in order to get a data bank, wich allows in the future to know better, the behaviour of each product and the factors that control their evolution.

\section{RESEARCHES}

Researches made in laboratories are focussed on the measurement, according to standards (e.g. C.N.R.-I.C.R.) or suggested methods (e.g. R.I.L.E.M., I.S.R.M.), of certain significant physical properties, in treated and non treated stones, analizyng later the characteristics of the stone-treatment system that have given rise to the variation in the values of these properties.

The physical properties usually measured are those related to the macroscopic aspect and brightness of the stone-colour-, to the voids -density and open porosity -, to the captation and humidity transfer through the interior of the stone - moisture and degree of saturation, capillary suction, water absorption and desorption, water vapour permeability-, the swelling of those lithological varieties having expansive clays -linear or volumetric hydric expansion-; also to the mechanical behaviour -modulus of elasticity, mechanical strength-, to the thermal behaviour -linear or volumetric thermal expansion-, contact angle, etc.

In some cases, these properties are measured again after the artificial or accelerated ageing tests, in order to correlate the durability of the treated and non-treated tested material, the weathering agent selected and the induced variations. 
La Tabla I ilustra algunos de los aspectos que acaban de mencionarse, en la caliza de Hontoria, material ampliamente utilizado en numerosos monumentos de la zona centro-norte de España (Castilla-León).

Las Figs. 1, 2 y 3 muestran el comportamiento frente al agua de esta misma caliza de Hontoria sin tratar, tratada y tratada y alterada artificialmente.

También suele compararse el comportamiento de las piedras monumentales, frente a diversos ensayos de alterabilidad tales como los de: humedad-sequedad, hielo-deshielo, cristalización
Table I illustrates some of the aspects that have just been mentioned in Hontoria limestone, a rock material widely used in many buildings of the Central-Northern area of Spain (Castilla-León).

Figs. 1, 2 and 3 show how the same Hontoria limestone, non-treated, treated and treated and artificially weathered, reacts to water.

The behaviour of monumental stones is compared, in many cases, by means of weatherability tests - wetting-drying, freezingthawing, salt crystallization, $\mathrm{SO}_{2}$ atmospheres,

TABLA I TABLE I

Caliza de Hontoria. Propiedades físicas. (Marcos, 1992)

[Hontoria limestone. Physical Properties. (Marcos, 1992)]

\begin{tabular}{|c|c|c|c|c|c|c|c|c|c|}
\hline & \multirow{3}{*}{$\begin{array}{l}\text { Sin } \\
\text { tratar } \\
\text { (Untrea- } \\
\text { ted) }\end{array}$} & \multicolumn{2}{|c|}{$\begin{array}{l}\text { Tratadas } \\
\text { (Treated) }\end{array}$} & \multicolumn{6}{|c|}{ Tratadas y alteradas (Treated and aged) } \\
\hline & & \multirow{2}{*}{ SSi } & \multirow{2}{*}{$\mathbf{R h}$} & \multicolumn{3}{|c|}{ SSi } & \multicolumn{3}{|c|}{$\mathbf{R h}$} \\
\hline & & & & H & 1 & C & H & 1 & C \\
\hline $\begin{array}{l}\rho_{d} \mathrm{~g} / \mathrm{cm}^{3} \text { densidad } \\
\left(\rho_{d} \mathrm{~g} / \mathrm{cm}^{3} \text { bulk density) }\right.\end{array}$ & 2,15 & 2,26 & 2,14 & 2,21 & 2,15 & 2,12 & 2,11 & 2,09 & 2,18 \\
\hline $\begin{array}{l}n_{0}(\%) \text { porosidad abierta } \\
\left(n_{0}(\%) \text { open porosity) }\right.\end{array}$ & 19,2 & 14,4 & 18,1 & 16,4 & 18,2 & 19,7 & 20,8 & 21,6 & 18,3 \\
\hline $\begin{array}{l}\text { Ws }(\%) \text { humedad de saturación } \\
\text { (Ws (\%) saturation water content) }\end{array}$ & 9,0 & 6,3 & 8,5 & 7,4 & 8,4 & 9,2 & 9,8 & 10,3 & 8,4 \\
\hline $\begin{array}{l}\mathrm{Sr}(\%) \text { grado de saturación } \\
(\mathrm{Sr}(\%) \text { degree of saturation) }\end{array}$ & 68,5 & 5,9 & 5,3 & 13,0 & 16,0 & 12,8 & 41,0 & 53,0 & 54,6 \\
\hline $\begin{array}{l}\mathrm{C}\left(\mathrm{Kg} / \mathrm{m}^{2} \cdot \mathrm{min}^{0,5}\right) \text { coeficiente de } \\
\text { capilaridad } \\
{\left[\mathrm{C}\left(\mathrm{Kg} / \mathrm{m}^{2} \cdot \mathrm{min}^{0,5}\right) \text { coefficient of }\right.} \\
\text { capillarity] }\end{array}$ & 30,6 & 0,4 & 0,7 & 0,7 & 0,8 & 0,4 & 0,8 & 1,0 & 0,9 \\
\hline $\begin{array}{l}\mathrm{Kv} \mathrm{g} /\left(\mathrm{m}^{2} \cdot 24 \mathrm{~h} \cdot \mathrm{mm} \mathrm{Hg}\right) \\
\text { permeabilidad al vapor } \\
{\left[\mathrm{Kv} \mathrm{g} /\left(\mathrm{m}^{2} \cdot 24 \mathrm{~h} \cdot \mathrm{mm} \mathrm{Hg}\right)\right.} \\
\text { water vapour permeability] }\end{array}$ & 5,6 & 2,0 & 4,3 & 3,0 & 1,9 & 2,7 & 4,5 & 4,2 & 4,3 \\
\hline
\end{tabular}

$\mathrm{SSi}=$ silicato de etilo + polisiloxano oligomérico (ethyl silicate + oligomeric polysiloxane); $\mathrm{Rh}=$ metil-fenil-polixiloxano (methyl-phenylpolysiloxane); $\rho_{d}=$ ISRM (1979); $n_{0}=$ ISRM (1979); $W_{c}=$ ISRM (1979); $S_{1}=$ ISRM (1979); C = Mamillan (1981); $K_{v}=$ NORMAL $21 / 85$ (CNR-ICR); $\quad H=$ Ensayo de humedad-sequedad (Wetting Druing Tests); 1 = Ensayo hielo-deshielo (Freezing Thawing Tests); C = Ensayo de cristalización de sales (Salt Crystallization Tests). 


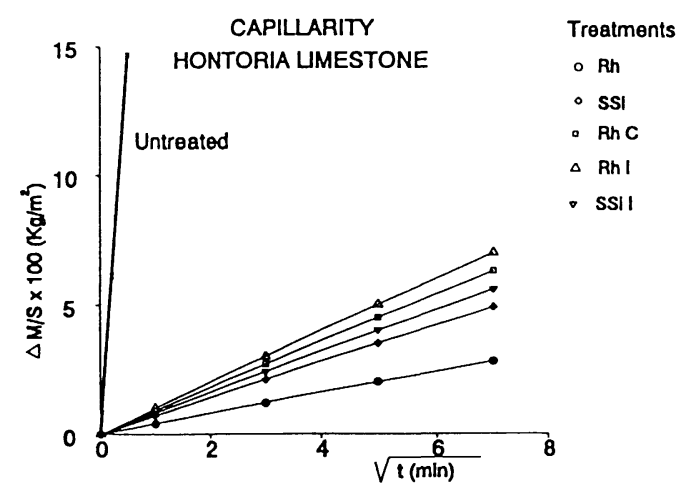

Fig. 1.-Absorción capilar de agua (Marcos, 1992). $\mathrm{Rh}=$ Metil-fenil-polisiloxano.

SSi = Silicato de etilo + silano oligomérico.

1 = Ensayo hielo-deshielo.

$\mathrm{H}$ = Ensayo humedad-sequedad.

C = Ensayo de cristalización de sales.

Fig. 1.-Capillary water absorption (Marcos, 1992).

$R h=$ Methyl-phenyl-polysiloxane.

SSi $=$ Ethyl-silicate + oligomeric polysiloxane.

$I$ = Freezing-Thawing Tests.

$H=$ Wetting-Drying Tests.

$C=$ Salt Crystallization Tests.
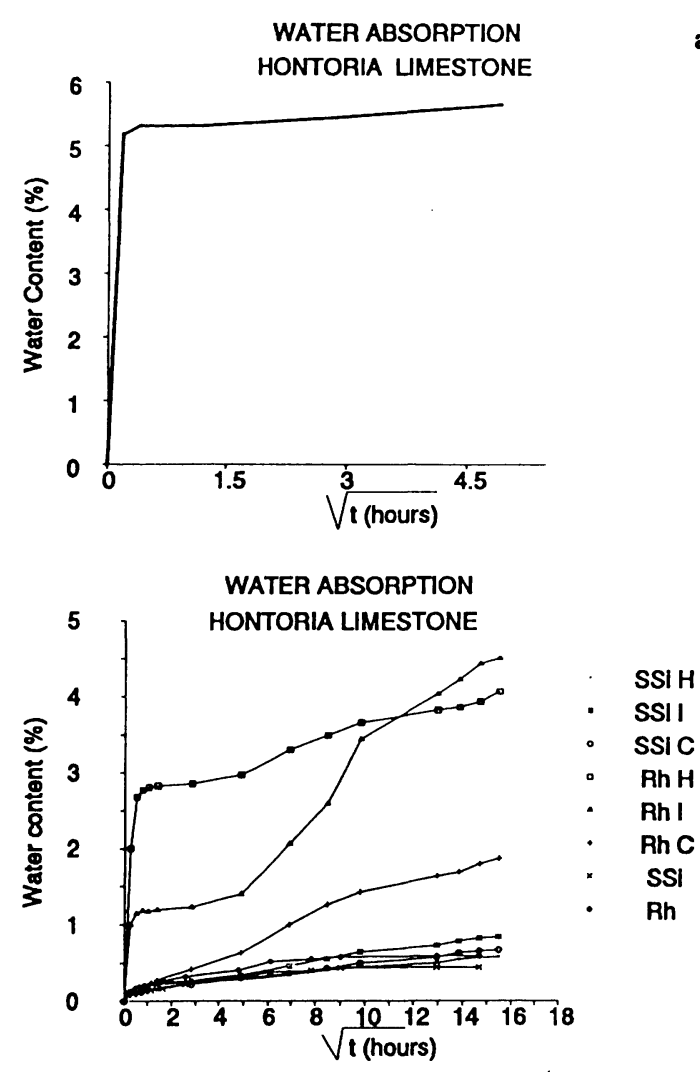

Fig. 2.-Absorción de agua por inmersión. a) Piedra no tratada; b) Piedra tratada y alterada artificialmente. (Marcos, 1992).

Fig. 2.-Immersion water absorption. a) Untreated; b) Treated and treated and artificially weathered. (Marcos, 1992).

a)
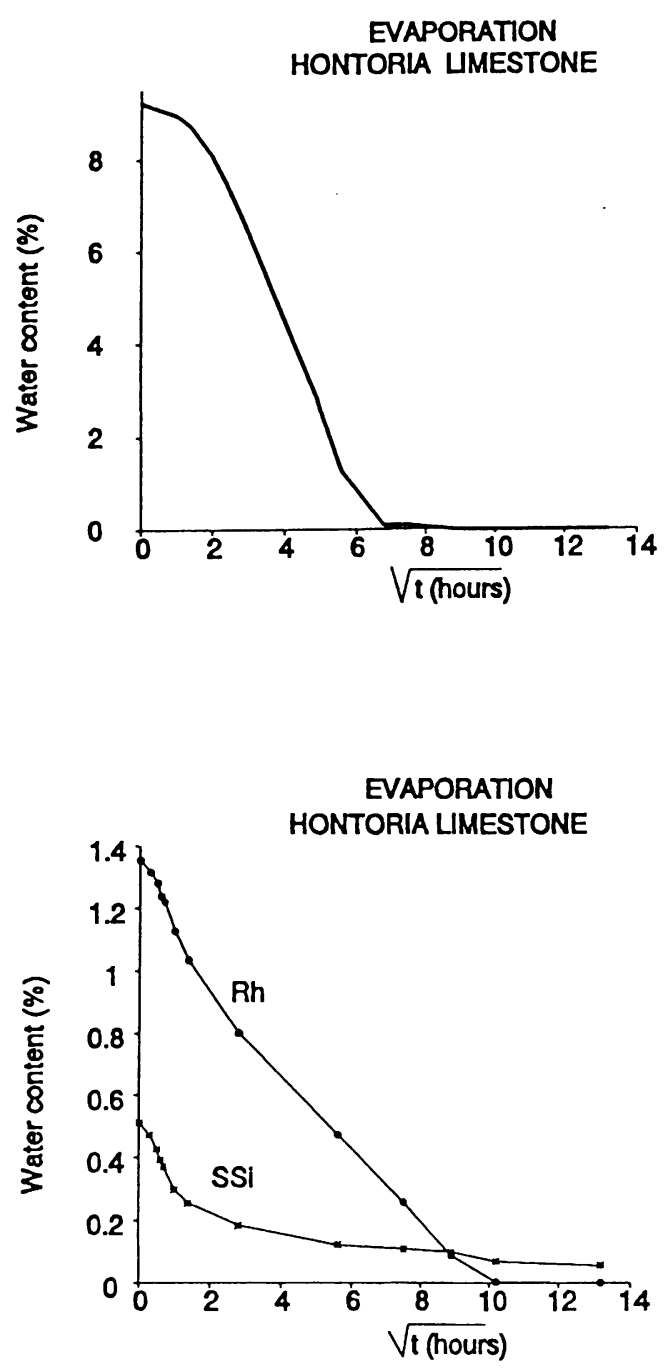

b)

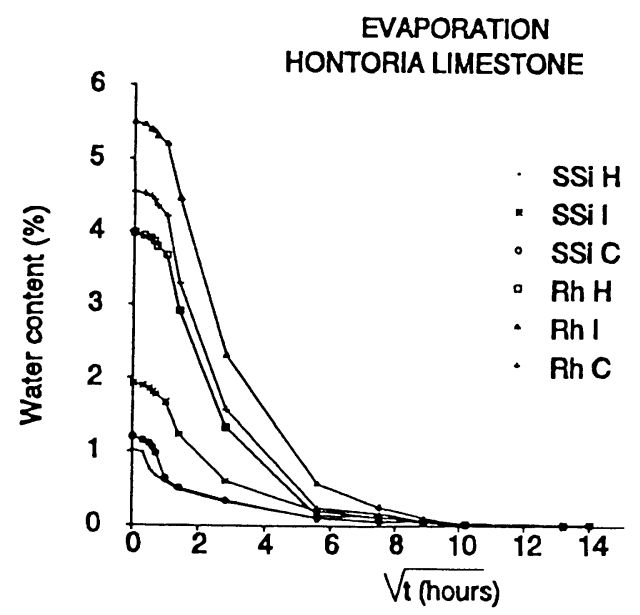

Fig. 3.-Evaporación de agua. a) Piedra no tratada, b) Piedra tratada; c) Piedra tratada y alterada artificialmente. (Marcos, 1992).

Fig. 3.-Water evaporation. a) Untreated stone; b) Treated stones; c) Treated and aged stones. (Marcos, 1992). 
de sales, atmósferas con $\mathrm{SO}_{2}$, exposición a las radiaciones ultravioletas, etc., en muestras $\sin$ tratar y tratadas con productos de distintas características químicas.

Se intenta así hacer predicciones sobre el comportamiento diferencial de los distintos tratamientos aplicados, a la vez que se obtiene información sobre el grado de agresividad de cada uno de los agentes de alteración seleccionados, para cada sistema piedratratamiento.

Los trabajos de Cabrera, 1979, Grossi, 1986; Esbert et al., 1987 (a y b), 1989 y 1991; Valdeón, 1989; Villegas et al., 1991; Alonso et al., 1992; Valdeón et al., 1992; Villegas y Vale, 1992; Bello et al., 1992 (a y b), Caro et al., 1992; Pavía et al., 1992; Marcos, 1992, etc.; hacen referencia a los diversos aspectos mencionados y en general, tratan rocas monumentales españolas de naturaleza sedimentaria: calizas, calizas margosas, dolomías, areniscas y calcarenitas, principalmente.

En estos trabajos se experimentan diversos productos de tratamiento, principalmente resinas acrílicas, metacrilatos, alquil-alcoxi-silanos, polisiloxanos, silicatos de etilo, poliuretanos y polímeros fluorados.

En algunos de ellos se aplican, separadamente y sobre un mismo tipo de piedra, diferentes productos de los antes mencionados. En otros se aplican diferentes sistemas consolidante-hidrofugante, tales como: silicato de etilo + polisiloxano oligomérico, resina acrílica + polisiloxano oligomérico, silicato de etilo + poliuretano, etc.

Por los resultados obtenidos en el conjunto de trabajos puede afirmarse que, los diferentes productos de tratamientos mencionados rebajan siempre, en mayor o menor medida, las propiedades hídricas de las piedras ensayadas, con lo que se pone de manifiesto que cumplen la finalidad de protección de la piedra frente al ambiente, para la que habían sido diseñados.

Sin embargo se pone también de manifiesto que, en las piedras tratadas, la evaporación del agua que eventualmente puede encontrarse en el interior de la roca es más lenta. En ocasiones, dependiendo del tipo de roca y tratamiento aplicado, a las 150 horas de ensayo en condiciones ambientales de $20^{\circ} \mathrm{C}$ y un $75 \%$ de humedad relativa, el contenido de agua en el interior de la piedra es significativo (Marcos, 1992). Este es un hecho que debe tomarse en consideración e intentar correlacionarlo con la evolución futura de la piedra hidrofugada. exposure to the ultraviolet radiations..., on nontreated specimens and other treated with products of different chemical characteristics.

It is intended to make predictions about the differential behaviour of the treatments applied and, at the same time, to get information about the aggressiveness of every single weathering agent selected, for each stone-treatment system.

The papers of Cabrera, 1979; Esbert at al., 1987 (a and b), 1989 and 1991; Valdeón, 1989; Villegas et al., 1991; Alonso et al., 1992; Valdeón et al., 1992; Villegas and Vale, 1992; Bello et al., 1992 ( $a$ and b); Caro et al., 1992 Pavia et al., 1992; Marcos, 1992, etc... allude to the different aspects already mentioned, and in general deal with Spanish monumental rocks of sedimentary nature: mainly limestone, marly limestone, dolostone, sandstone and calcarenites among others.

Several treatment products are experimented in these papers: mainly acrylic resin, methacrylates, alkyl-alkoxy silanes, polysiloxanes, ethyl silicates, polyurethanes and fluorinated polymers.

In some of these studies different products already mentioned are applied on the same type of stone. In other cases, different consolidanthydrophobing systems are applied: ethyl silicate + oligomeric polysiloxane, acrylic resin + oligomeric polysiloxane, ethyl silicate + polyurethane, etc.

As a result of this, it can be stated that the hydric properties of the stones tested are more or less reduced by those treatment products, so that they fulfil the purpose to which they were designed; that is, the protection of the stone in the environment.

However, it also makes clear that, in treated stones, the evaporation of the water that can be eventually found in the interior of the rock is very slow. Sometimes, and according to the type of rock and treatment applied, the water content in the interior of the stone is significant, after 150 hours of evaporation under environmental conditions of $20^{\circ} \mathrm{C}$ and $75 \%$ of relative hymidity (Marcos, 1992). This fact has to be born in mind and try to correlate with the future evolution of the protected stone. 
Puede afirmarse, ya refrendado por una suficiente experimentación, que la presencia de anisotropías texturales en las piedras, así como de determinados tipos arcillas y sus porcentajes, condicionan una mala evolución de los citados tratamientos, en general.

Las diferentes respuestas de las piedras tratadas a los ciclos de envejecimiento acelerado está en estrecha relación con las variaciones inducidas, por cada uno de los tratamientos, en la configuración de su sistema poroso.

Este hecho está a su vez, estrechamente relacionado con la profundidad y modo de penetración de cada uno de los tratamientos, en los espacios vacíos de las piedras.

Referente a estos dos últimos aspectos existen algunos trabajos referidos a rocas monumentales españolas tales como Hammecker et al., 1992; Marcos 1992, Díaz-Pache, 1992, etc, en los que se analizan, mediante porometría de mercurio, las variaciones de la porosidad y de los tamaños de los poros en rocas tratadas, desde la superficie tratada hacia el interior, hasta llegar al nivel en el que ya no ha penetrado el tratamiento, Fig. 4.

Estos trabajos ponen de manifiesto que, frente a un mismo producto de tratamiento, la penetración en el material rocoso depende más de los tamaños de los accesos a los poros que del valor de la porosidad.

Así por ejemplo, en la caliza de Hontoria con una porosidad abierta del $23 \%$, un silicato de etilo aplicado por capilaridad, ha penetrado hasta 5 $\mathrm{cm}$. En la dolomía de Laspra, con un valor más elevado de la porosidad abierta, superior al $30 \%$, el mismo tratamiento aplicado en las mismas condiciones, no penetra más que $5 \mathrm{~mm}$. Ello está directamente relacionado con el tamaño de los poros y la configuración de sistema poroso de una y otra roca.

La Fig. 5 muestra, en la caliza de Hontoria, el volumen de poros penetrados por mercurio en piedras no tratadas y tratadas con dos productos diferentes, en relación al radio de acceso de los mismos. La curva de frecuencia de distribución de radios de acceso es diferente en cada caso.

En Marcos, 1992, se comprueba
The durability of the tested stones generally improves with the treatments, no matter the weathering agent, but for some rocks with certain treatment products.

This latter fact, related to some types of rocks and treatments, is discussed in some studies (Marcos, 1992).

Thus, it can be stated, as it has been widely experimented, that the presence of textural anisotropies in stones, as well as certain types of clays and their percentages, generally condition a poor evolution of the treatments.

The different behaviours of the treated stones with respect to the accelerated ageing cycles is closely linked with the induced changes, for each one of the treatments, in the structure of its pore system.

This fact is at the same time closely related to the depth and the way each product penetrates in the voids of the stones.

As far as these two aspects is concerned, there are some studies published referring to spanish monumental rocks, such as: Hammecker et al., 1992; Marcos, 1992; Díaz-Pache, 1992.

Porosity variations and the pore size distribution in treated stones are analyzed in these studies by means of mercury porosimetry, from the treated surface towards the interior until the level where the treatment has not penetrated, Fig. 4.

In these researches, it can be stated that the penetration in the stone material depends more on the size of the accesses to the pores than on the porosity value, provided that the same treatment product is used.

For instance, in Hontoria limestone, with an open porosity of $23 \%$, the ethyl silicate, applied by capillarity, has penetrated until $5 \mathrm{~cm}$. In Laspra dolostone, with higher open porosity, over $30 \%$, the same product applied in the same conditions only penetrates between 5-10 $\mathrm{mm}$. This is directly related to the size of the pores that make up the pore system of each rock.

Fig. 5 shows, in Hontoria limestone, the pore volume penetrated by mercury in non-treated an treated stones, with two different products, in relation to the radius of the access to the pores. The frequency curve of the pore distribution is different in each case.

In Marcos, 1992, it is experimentally verified how 
a)

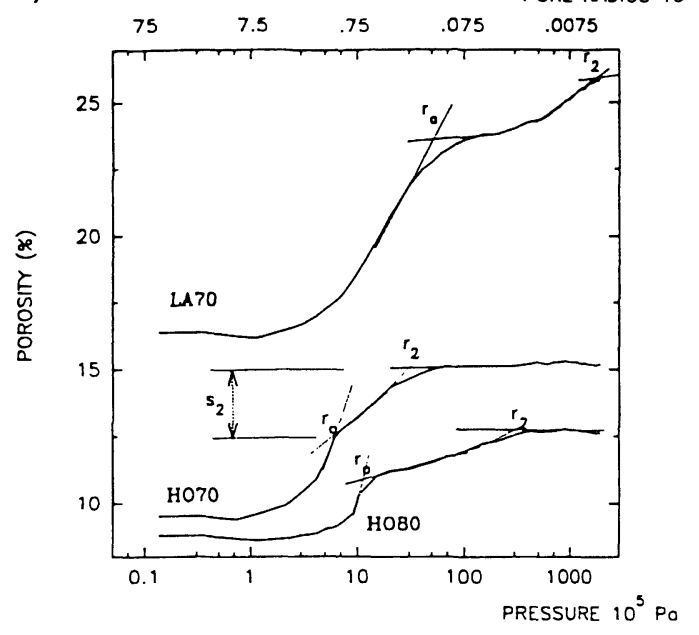

b)

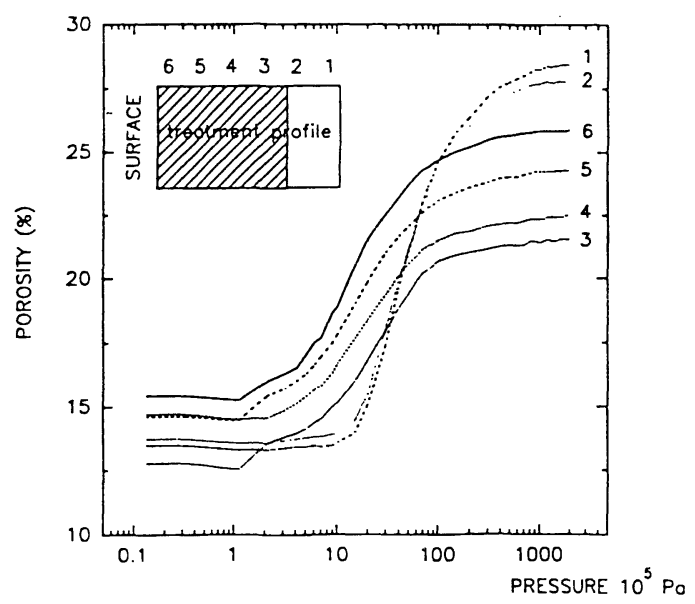

Fig. 4.-a) Curvas de la segunda inyección de mercurio, correspondiente a cortes sucesivos desde la parte externa del perfil de tratamiento de Laspra y Hontoria. b) Curvas de la segunda inyección de mercurio a lo largo del perfil de tratamiento de LA80.

LA70 = Piedra de Laspra tratada con silicato de etilo.

LA80 = Piedra de Laspra tatada con silicato de etilo y resina silicónica.

$\mathrm{HO70}=$ Piedra de Hontoria tratada con silicato de etilo.

Fig. 4. -a) Second mercury injection curves for slabs caught on the external surface of treatment profile of Laspra and Hontoria. b) Second mercury injection curves along the treatment profile of LA80 (Hammecker, Esbert y Jeannette, 1992).

LA70 = Laspra stone treated with ethyl silicate.

LA80 = Laspra stone treated with ethyl silicate and silicon resin.

HO7O = Hontoria stone treated with ethyl silicate.

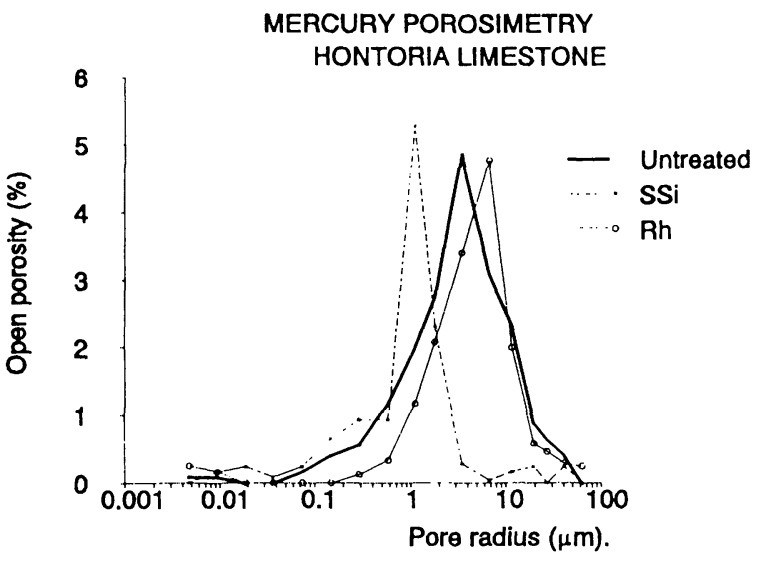

experimentalmente cómo la nueva configuración del sistema poroso, inducida por uno $u$ otro tratamiento en cada tipo de roca, condiciona en gran medida su comportamiento en los ensayos de durabilidad.

Las piedras que presentan una relación porosidad atrapada/porosidad abierta próxima a uno, y aquéllas a las que los tratamientos confieren esta característica (aumento de la porosidad atrapada), tienen un buen comportamiento frente a los agentes de alteración.
Fig. 5.-Porosimetría de mercurio. Caliza de Hontoria sin tratar y tratada. (Marcos, 1992).

SSi $=$ Silicato de etilo + polisiloxano oligomérico

$\mathrm{Rh}=$ Metil-fenil-polisiloxano.

Fig. 5.-Mercury porosimetry. Untreated and treated Hontoria limestone (Marcos, 1992).

$S S i=$ Ethyl silicate + oligomeric polysiloxane.

$R h=$ Methyl-phenyl-polysiloxane.

the new framework of the pore systm, which has been induced by one treatment or another, determines to a great extent its durability.

So, the stones which have a ratio trapped porosity/open porosity next to 1 , and those with this feature (increase of trapped porosity) due to treatments, have a good behaviour under the weathering agents. 
TABLA \| TABLE \|

Caliza de Hontoria. Permeabilidad al vapor de agua $\left(\mathrm{g} / \mathrm{m}^{2} \cdot 24 \mathrm{~h} \mathrm{~mm} \mathrm{Hg}\right)$.

NORMAL 21/85 (CNR-ICR) (Marcos, 1992)

[Hontoria limestone. Water Vapour Permeability $\left(\mathrm{g} / \mathrm{m}^{2} \cdot 24 \mathrm{~h} \mathrm{~mm} \mathrm{Hg}\right)$.

NORMAL 21/85 (CNR-ICR) (Marcos, 1992)]

\begin{tabular}{|l|c|c|c|c|c|}
\hline \multirow{2}{*}{ ROCK TYPE } & \multirow{2}{*}{ Untreated } & \multicolumn{4}{c|}{ Treated } \\
\cline { 3 - 7 } & & SSi & Rh & Si & Dr \\
\hline DOLOSTONE. Boñar aguas & 9,7 & 2,7 & 3,7 & & \\
\hline MARLYLIME STONE. Pais clara & 7,0 & 2,3 & 3,1 & & \\
\hline LIMESTONE. Hontoria & 5,6 & 2,0 & 4,3 & & 2,9 \\
\hline DOLOSTONE. Boñar bueno (Quarry) & 4,1 & 1,1 & 1,4 & & 1,4 \\
\hline LIMESTONE. Hontoria (Quarry) & 7,0 & & & 4,9 & 5,0 \\
\hline
\end{tabular}

$\mathrm{SSi}=$ ethyl silicate + oligomeric polysiloxane (Wacker OH + Wacker 290L); $\mathrm{Si}=$ Oligomeric polysiloxane (Wacker $290 \mathrm{~L}) ; \mathrm{Rh}=\mathrm{Methyl}$ phenyl polysilozane (Rhodorsil 11309); $\mathrm{Dr}=$ Oligomeric polysiloxane (Dry Film 104).

También se corrobora, en los diferentes trabajos sobre rocas monumentales españolas que todos los tratamientos de protección rebajan la permeabilidad al vapor, aunque de forma menos notoria a cómo rebajan los valores de otras propiedades hídricas.

Así, por ejemplo, en la Tabla II aparecen los valores de permeabilidad al vapor de algunas rocas carbonatadas, utilizadas en la Catedral de León (España), sin tratar y tratadas con diferentes productos.

En cuanto a los distintos productos de tratamiento antes mencionados, y sobre los que ya se tienen diversas experiencias en su aplicación a rocas sedimentarias de diferente composición química, puede afirmarse que los silicorgánicos son siempre los que resultan más idóneos en cuanto que tienen una evolución más favorable frente a la alterabilidad.

De entre ellos son los silicatos de etilo los que ofrecen, según los experimentos de laboratorio, mejores garantías en general, para el tratamiento de las piedras antes mencionadas.

La aplicación conjunta de un consolidante más un hidrorrepelente mejora, en mayor medida, las perspectivas de durabilidad de las piedras.
It is also verified in these researches, that all protection treatments reduce the water vapour permeability, although in a less remarkable way as the values of other properties.

Thos, for instance, Table II shows the water vapour permeability values of some carbonated rocks used in León cathedral (Spain), non-treated and treated with different products.

There are already experiences in the application of the products above mentioned before to sedimentary rocks of different chemical composition. It can be stated that the silicoorganics ones are always the most suitable since they have a better evolution in relation to weatherability.

Among these products, the ethyl silicates are the most succesful in general for the treatment of the stones mentioned before.

The application of both a consolidant and a waterrepellent altogether improves the durability prospects of the stones. 
La presencia de sales solubles en el interior de la piedra, hace que los tratamientos en ellas aplicados evolucionen negativamente, provocando el desprendimiento paulatino de la capa de tratamiento junto con piedra del substrato, o la fracturación a lo largo de la interfase piedra tratada/piedra sin tratar, (Esbert et al., 1991).

Los resultados del ataque químico de piedras carbonatadas, utilizadas en diversas catedrales de Andalucía, (Sur de España), tratadas con resinas acrílicas y productos silicorgánicos, con atmósferas de $1.000 \mathrm{ppm}$. de $\mathrm{SO}_{2}$, según Villegas y Vale, 1992, ponen en evidencia que la respuesta de las muestras tratadas con estos productos es similar, para las condiciones de ensayo programadas. Al final de los ensayos la hidrorrepelencia de las muestras desaparece, lo que hace suponer que los productos aplicados se han deteriorado completamente.

\section{AGRADECIMIENTOS}

- A la Comisión Interministerial de Ciencia y Tecnología (CICYT) Proyecto n. ${ }^{\circ}$ PAT-911.093-C03-01, por el soporte científico de esta línea de investigación.

- Al Centro Gino Bozza del Politécnico de Milán, por su invitación, a participar en la Mesa Redonda que sobre: "La utilización mundial de protectores para la conservación de la piedra monumental", tuvo lugar en Viterbo (Italia), el pasado mes de octubre.

- A la Dra. Marisa Laurenzi-Tabasso del ICCROM de Roma, por su apoyo y colaboración en todos aquellos trabajos que sobre tratamiento de la piedra, se vienen realizando en nuestro grupo de trabajo.

- También a la Dra. Giovanna Alessandrini del ya citado Centro Gino Bozza de Milán.
The results of the chemical attack of stones, used in several cathedrals in Andalucia (South of Spain), treated with acrylic resins and silicoorganic products with and atmosphere of $1000 \mathrm{ppm} \mathrm{SO}_{2}$, according to Villegas and Vale, 1992, evidence that the answer of the specimens treated with these products are similar for the programmed testing conditions.

The presence of soluble salts in the interior of the stone makes the treatment applied in it develop in an unfavourable way, bringing about the gradual detachment of the treatment layer together with part of the substratum or the breaking up along the interphase treated /non-treated stone (Esbert et al, 1991).

\section{ACKNOLEDGEMENTS}

- The "Comisión Interministerial de Ciencia y Tecnologia" (CICYT), for financing several projects related to the conservation of monumental stones, mainly the last one: PAT91-1093-C03-01.

- To the "Gino Bozza" Centre of Milan Polytechnics, for its invitation to participate in the Round Table celebrated in the $3 .^{\text {rd }}$ Int. Conference on Non-destructive Testing for Study and Conservation of Works of Art (Viterbo, Italy, 1992).

- To Dra. Marisa Laurenzi Tabasso, ICCROM, Rome for the advice and support in the subjects about stone treatment.

- To Dra. Giovanna Alessandrini, from the above mentioned "Gino Bozza" Centre, Milan.

\section{REFERENCIAS}

\section{REFERENCES}

ALONSO, F. J., ORDAZ, J., PÉREZ, A. and ESBERT, R. M., (1992): "Laboratory study of a treated dolostone subjected to thermal cycles". 7th Int. Cong on Deterioration and Conservation of Stones". Lisbon, 1992, pp. 745-551.

BELLO, M. A., MARTIN, L. and MARTIN, A., (1992) a: "Preliminary evaluation of the water-proofing efficacy of diverse protective treatments on diverse stones used in spanish monuments" 7th Int. Cong. on Deterioration and Conservation of Stones". Lisbon, 1992, pp. 1273-1277.

BELLO, M. A., MARTIN, L. and MARTIN, A., (1992) B: "Decay and treatment of Macael white marble". Studies in Conservation, vol. 37, N. 3, pp. 193-200.

CABRERA, J. M. (1979): "Causas de alteración y métodos de conservación aplicables a los monumentos hechos en piedra". Materiales de construcción, n. ${ }^{2} 174$, pp. 1-38. 
CARO, S., PAVIA, S., GÓMEZ, F. and ALVARES, J. A. (1992): "The preservation of the stone in the Cathedral of "St. M." la Redonda". Logroño (La Rioja), Spain. 7th Int. Cong. on Deterioration and Conservation of Stones". Lisbon, 1992, pp. 1327-1334.

DIAZ-PACHE, F. (1992): "Técnicas instrumentales aplicadas al conocimiento de la penetración de consolidantes en rocas carbonatadas, y sus efectos en el sistema poroso". Tesis de Licenciatura. Área de Petrología y Geoquímica. Dpto. de Geología. Universidad de Oviedo, 30p.

ESBERT, R. M., GROSSI, C. and MARCOS, R. M., (1987) a: "Laboratory studies on the consolidation and protection of calcareous materials in the Cathedral of Oviedo. Part. I. Materiales de Construcción. Vol. 37, n. ${ }^{8} 206$, pp. 17-27.

ESBERT, R. M., GROSSI, C. and MARCOS, R. M., (1987) b: "Laboratory studies on the consolidation and protection of calcareous materials in the Cathedral of Oviedo. Part. II. Materiales de Construcción. Vol. 37, n. ${ }^{2} 208$, pp. 13-21.

ESBERT, R. M., GROSSI, C. M., VALDEÓN, L., ORDAZ, J., ALONSO, F. J. and MARCOS, R. M., (1989): "Studies ofr stone conservation at the Cathedral of Murcia (Spain)". The Conservation of Monuments in the Mediterranean Basin, Bari, pp. 437-441.

ESBERT, R. M., GROSSI, C., ORDAZ, J., and ALONSO, F. J., (1991): "La conservación de la piedra de la Casa Milá ("La Pedrera" de Gaudi, Barcelona): Pruebas preliminares". Boletón Geológico y Minero. Vol 102-3, pp. 446-454.

GROSSI, C. M., (1986): "Ensayos de tratamiento en materiales rocosos de la Catedral de Oviedo". Tesis de Licenciatura. Área de Petrología y Geoquimica Dpto. de Geología. Universidad de Oviedo, 122 p.

HAMMECKER, C., ESBERT, R. M. and JEANNETTE, D., (1992): "Geometry modifications of porous network in carbonate rocks by ethyl silicate treatment". 7th Int. Cong. on Deterioration and Conservation of Stone. Lisbon, 1992, pp. 1053-1062.

MARCOS, R. M., (1992): "Tratamientos de conservación aplicados a rocas carbonatadas: Catedral de León". Tesis Doctoral. Área de Petrología y Geoquímica Dpto. de Geología. Universidad de Oviedo, 273 p.

PAVÍA, S., CARO, S., PÉREZ, F., and LÓPEZ, F., (1992): "Protection of the stone of "San Bartolome" church in Logroño (La Rioja), Spain". 7th Int. Cong. on Deterioration and Conservation of Stone. Lisbon, 1992, pp. 1335-1340.

VALDEÓN, L., (1989): "Comportamiento hídrico de dolomías calizas y areniscas de las Catedrales de León, Sevilla y Salamanca, Aplicabilidad a la conservación de rocas monumentales". Tesis Doctoral. Área de Petrología y Geoquímica Dpto. de Geología. Universidad de Oviedo, $234 \mathrm{p}$.

VALDEÓN, L., GROSSI, C. M., MARCOS, R. M. and ESBERT, R. M. (1992): "Effect of conservation treatments on hydric properties of stones". 7th Int. Cong. on Deterioration and Conservation of Stone. Libon 1992, pp. 1093-1081.

VILLEGAS, R., VALE, J. F. and ALCALDE, M., (1991): "Evaluación de tratamientos de hidrofugación aplicados a piedra calizas de Catedrales Andaluzas". Materiales de Construcción. Vol. 41, n. ${ }^{2} 223$, pp. 19-27.

VILLEGAS, R., VALE, J. F., (1992): "Evaluation of the behaviour of water repellent treatment for stone". 7th Int. Cong. on Deterioration and Conservation of Stone. Lisbon, 1992, pp. 1253-1263.

\section{publicación del ICCET/CSIC}

\section{INSPECCION DE OBRAS DAÑADAS POR CORROSION DE ARMADURAS}

El presente Manual va dirigido principalmente a técnicos especializados y laboratorios que tienen que intervenir en el dictamen de la situación de deterioro de estructuras de hormigón armado dañadas por corrosión de armaduras.

Comienza con un resumen recordatorio de los factores principales a los que se pueden deber los daños prematuros por corrosión de armaduras, para seguir con algunas indicaciones de cómo se deben realizar las inspecciones, y de los ensayos y la metodología que se recomienda realizar para poder dictaminar con precisión las causas de daño.

A continuación se hacen una serie de comentarios sobre la vida residual de estructuras dañadas, sobre el riesgo de corrosión futura, el seguimiento necesario de una estructura reparada y una breve enumeración de métodos de reparación y consideraciones básicas a tener en cuenta en la recomendación de un determinado método. Se aporta una breve relación bibliográfica.

Finalmente se incluyen en forma de ficha la descripción de algunos casos de corrosión de armaduras detectados en nuestro país. manual

inspección de obras dañadas por corrosión de armaduras 